\title{
高純度フェライト系ステンレス冷延鋼板の耐二次加エ 脆性に及ぼす結晶粒径およびボロンの影響
}

\author{
札軒＼cjkstart富美夫*・住友 秀彦*2 \\ Effect of Grain Size and Boron on Resistance to Secondary Working Embrittlement of \\ High-purity Ferritic Stainless Cold-rolled Steel Sheet
}

Fumio FUDANOKI and Hidehiko SUMITOMO

Synopsis : The effect of grain size and boron on the resistance to the secondary working embrittlement of high-purity ferritic stainless cold-rolled steel sheet is investigated and analyzed. The mechanism for improving the resistance to the secondary working embrittlement by adding boron to high-purity ferritic stainless steel sheet is studied from the standpoint of the behavior of the segregated boron. The results obtained are as follows.

(1) The secondary working embrittlement in Ti stabilized low C, N ferritic stainless steel sheet occures by the interganular fracture.

( 2 ) Refining the grain size improves the resistance to the embrittlement, but it remarkably deteriorates the deep drawing property.

( 3 ) Adding boron improves the resistance to the embrittlemnt, with ensuring the deep drawing property.

( 4 ) The morphology of fracture in the secondary working embrittlement changes from the intergranular fracture to the cleavage fracture by adding boron.

( 5 ) It is considered that the improvement of the resistance to the working embrittlement is due to strengthening the grain boundary by the segregated boron to the grain boundary instead of carbon. This agrees with the results obtained in the interstitial-atom free steel sheets.

Key words : ferritic stainless steel; deep drawing; boron; grain boundary; interglanular fracture; secondary working embrittlement.

\section{1. 緒言}

ステンレス冷延鋼板において，厨房用シンク等の過酷な プレス成形を要求される部材には，従来からSUS304に代 表されるオーステナイト系ステンレス鋼板が主に使用され ている。これに対して，近年SUS430の深絞り性を高める ためにTiや $\mathrm{Nb}$ を添加し, 固溶 $\mathrm{C}, \mathrm{N}$ を析出固定した高純度 フェライト系ステンレス鋼板 ${ }^{1-3)}($ SUS430LX)が適用されつ つある。しかしながら，高純度フェライト系ステンレス 鋼板は，冬場や気温の低い地方で深絞り加工を行い，次い で張出し成形やフランジ・カット等の二次加工を施した場 合, 加工品のコーナー部の側壁に縦割れと呼ばれる二次加 工脆化が発生しやすい ${ }^{4)}$

二次加工脆化については，極低炭素鋼板（以下， IF [Interstitial-atom Free] 鋼板と呼ぶ）に関して多くの研究が行 われている ${ }^{5-9)}$ 。IF鋼板は深絞り加工後に衝撃的な高速変 形を受けると，粒界脆性破断を発生することがある5)。高 橋らは，二次加工脆化に対する脆性・延性遷移温度は Ti 添加 IF 鋼板へのボロン $(\mathrm{B})$ 添加により大幅に低温化すると 報告している ${ }^{6}$ 。この報告において，固溶Bの存在による 粒界破壊抑制のメカニズムには二つのモデルが提案されて
いる。第一のモデルは，いわゆるサイトコンペティション 効果 ${ }^{10)}$ であり，固溶Bが比較的小さな原子半径を有するた め，粒界に優先的に偏析し P 偏析を抑制するものである。 第二のモデルは，粒界に偏析した B 原子自体が粒界におけ る Fe原子間の結合力を向上させるものである ${ }^{11.12) 。 ~}$

一方，フェライト系ステンレス鋼板の二次加工脆化に関 する研究は少ない。SUS430およびTi, Nbを添加した低炭 窒素 $13 \mathrm{Cr}, 17 \mathrm{Cr}$ 鋼の耐二次加工脆性に及ぼす化学成分の影 響が宮楠らにより報告されている4)。この報告によると， 耐二次加工脆性は $\mathrm{Ti} /(\mathrm{C}+\mathrm{N})$ あるいは $\mathrm{Nb} /(\mathrm{C}+\mathrm{N})$ で整理で き, $(\mathrm{C}+\mathrm{N})$ 量に対する $\mathrm{Ti}, \mathrm{Nb}$ 量が 5 倍程度までの微量添加 であれば，耐二次加工脆性はSUS430に比べて若干向上す るが， $\mathrm{Ti} ， \mathrm{Nb}$ がにに多くなると逆に劣化する。一方， SUS430では二次加工による粒界破断は高純度フェライト 系ステンレス鋼に比べ極めて起こりにくい。

そこで，本研究では高純度フェライト系ステンレス鋼板 における耐二次加工脆性に及ぼす結晶粒径およびB量の影 響を明らかにする。さらに，高純度フェライト系ステンレ ス鋼板のB添加による二次加工脆化の改善メカニズムにつ いて，Bの粒界偏析挙動の点から検討したので報告する。

*2 新日本製鐵（株）八幡技術研究部 (現：(株) 超高温材料研究センタ一) (Yawata R\&D Lab., Nippon Steel Corp., now Japan Ultra-high-Temperature Materials Research Center) 


\section{2. 実験方法}

実験に供した鋼は，45 kgラボ真空溶解により準備した。 供試材の化学成分を Table 1 に示すが，17\% Cr-0.5\% Ti$0.01 \% \mathrm{C}-0.01 \% \mathrm{~N}$ の $\mathrm{Ti}$ 添加低炭窒素 $17 \mathrm{Cr}$ フェライト系ステ ンレス鋼を基本成分とし，鋼中の B 量の効果を検討するた め，B量を $0.0002 \sim 0.0038 \%$ の範囲で変化させた。供試材 の製造工程を Fig. 1に示す。供試材は，実験室の熱間圧延 ラインを用いて $1180^{\circ} \mathrm{C}$ 加熱後熱間圧延を行い, 板厚 $6 \mathrm{~mm}$ の熱延板を得た。次いで， $900^{\circ} \mathrm{C}$ で熱延板焼鈍を行い，2 回冷延 - 2 回焼鈍法により板厚 $0.8 \mathrm{~mm}$ の冷延焼鈍板を得 た。最終焼鈍は主として $850^{\circ} \mathrm{C} て ゙$ 行った。B無添加材 $(\mathrm{B}=2 \mathrm{ppm})$ につては結晶粒度の影響を検討するため, 最 終焼鈍の温度を $800 \sim 925^{\circ} \mathrm{C}$ の範囲で変化させた。結晶粒 度（図中では，G.S.N. [Grain Size Number]と略する）は， 7.0 (円相当換算の粒径で $35.3 \mu \mathrm{m}$ ） から $9.2(16.5 \mu \mathrm{m})$ まで 変化した。ここで, 焼鈍後の結晶粒が整粒であるので, JIS G 0552 の切断法に従い圧延方向の板厚断面組織の結晶 粒度を測定した。

二次加工性を調べるための評価方法を Fig. 2 に示す。評 価方法はブランクサイズが $84.0 \mathrm{~mm} \phi$ の円板を用いて $40.0 \mathrm{~mm} \phi$ の円筒カップに絞り加工（絞り比 2.1）し, 次い でその側壁に重さ $2 \mathrm{~kg}$ の鍾を自由落下させ割れを発生させ た。これらの落重試験は, 高さが50 1000 mmで温度が $-20 \sim 40^{\circ} \mathrm{C}$ 範囲で変化させた。落重試験後の円筒カップ を Fig. 3 に示す。二次加工性は，同図に示すように，カッ プの側壁において縁から底方向に直線状に延びた縦割れの

Table 1. Chemical compositions.

\begin{tabular}{|c|c|c|c|c|c|c|c|c|c|}
\hline $\mathrm{C}$ & $\mathrm{Si}$ & $\mathrm{Mn}$ & $\mathrm{P}$ & $\mathrm{S}$ & $\mathrm{Ni}$ & $\mathrm{Cr}$ & $\mathrm{Ti}$ & $\mathrm{N}$ & $\mathrm{B}$ \\
\hline 0.01 & 0.14 & 0.83 & 0.026 & 0.006 & 0.10 & 16.3 & 0.47 & 0.01 & $\begin{array}{c}0.0002 \\
S \\
0.0038\end{array}$ \\
\hline
\end{tabular}

有無により評価した。引張特性は, 異方性の把握のために 圧延方向に対して $0^{\circ} ， 45^{\circ} ， 90^{\circ}$ 方向からそれぞれJIS13号 $\mathrm{B}$ 試験片を採取し，インストロン型引張試験機を用いて降 伏応力, 引張強さ, 破断伸びを測定した。 $r$ 值（塑性歪比 またはランクフォード值）は，圧延方向に対して $0^{\circ}, 45^{\circ}$, $90^{\circ}$ 方向からそれぞれJIS13 号 B 試験片を採取し，歪量 $14.4 \%$ 与える引張変形の前後での試験片厚み $\left(t_{0}, t\right)$ と幅 $\left(w_{0}, w\right)$ を測定して次式を用いて算出した。

$$
r=\frac{\ln \left(w_{0} / w\right)}{\ln \left(t_{0} / t\right)}
$$

リジング高さは，圧延方向が最も顕著に発生するので， 圧延方向からJIS5 号試験片採取し, 歪量 $16 \%$ 引張変形を 与えた後，表面粗さ計を用いて試験片表面プロフィールを

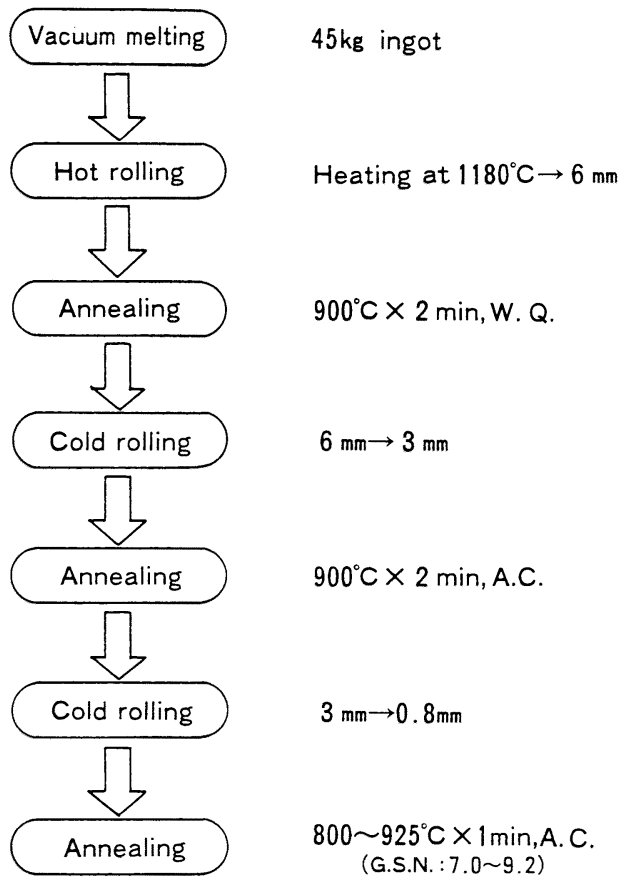

Fig. 1. Manufacturing process.

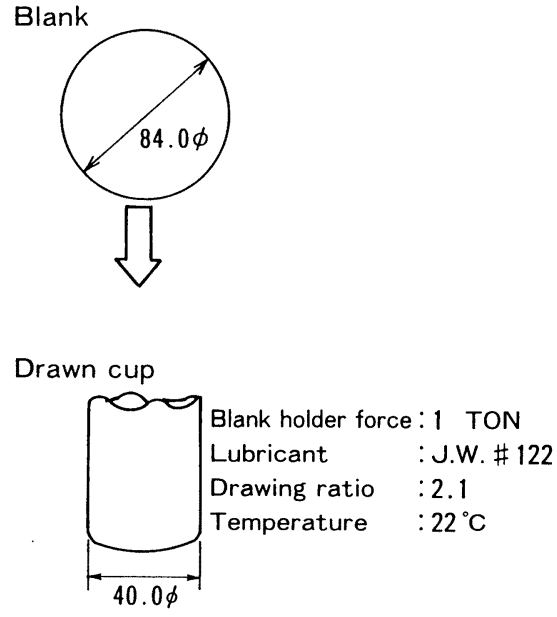

(a) 1 step drawing

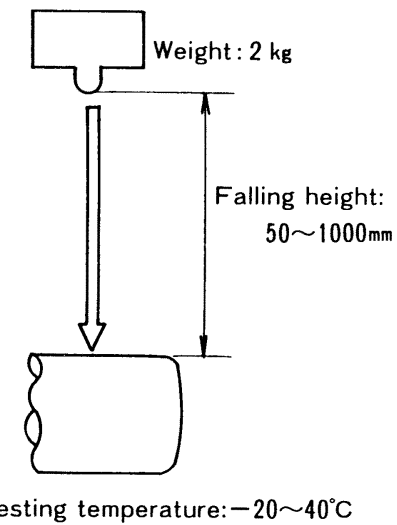

(b) test set-up

Fig. 2. Testing method for evaluation of embrittlement after press forming. 


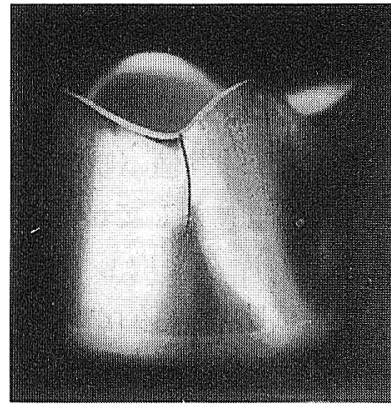

Fracture

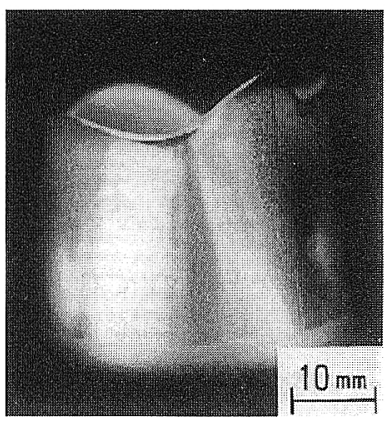

No fracture
Fig. 3. Cylindrical cups obtained by test for evaluation of embrittlement after press forming.

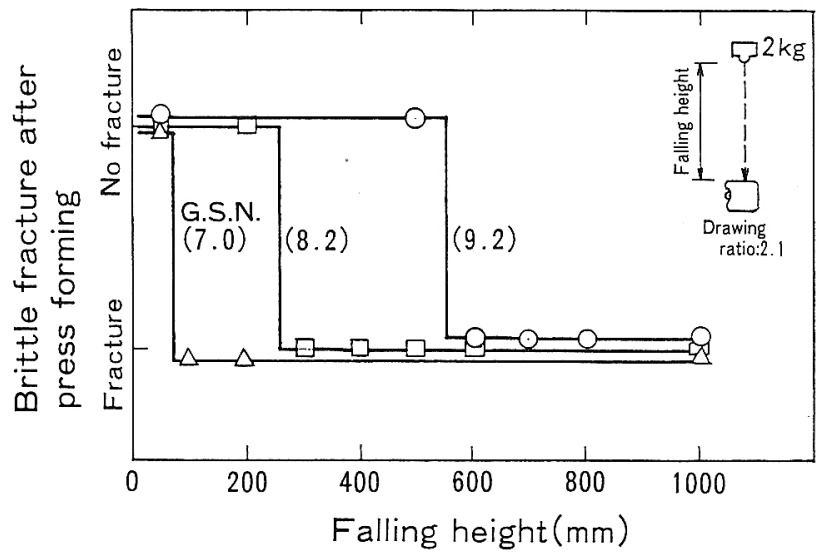

Fig. 4. Effect of grain size of annealing sheet on falling height for occurrence of brittle fracture after press forming at $25^{\circ} \mathrm{C}(\mathrm{B}: 2 \mathrm{ppm})$.

試験片幅方向に測定し, 最大粗さ $\left(R_{\text {max }}\right)$ から算出した。ま た，円筒カップの二次加工脆化の割机破面を走査型電子顕 微鏡(SEM)で観察した。最終焼鈍板の集合組織打よび析出 B量を空れでれX線回析，抽出残渣分析（抽出液：アセチ ルアセトン系電解液）により測定した。さらに，最終焼鈍

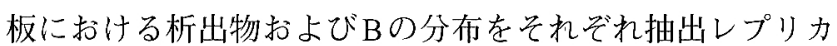
法,フィッショントラック法5゙により観察した。

\section{3. 実験結果および考察}

\section{$3 \cdot 1$ 結晶粒度の影響}

B 無添加材に打ける二次加工脆化の形態を把握するた め，結晶粒度の影響を調べた。

B無添加材における二次加工脆化の発生高さに及洼す結 晶粒度の影響を Fig. 4 に, 脆化の割れ破面の走查電顕像を Fig. 5 に示す。二次加工脆化の発生高さは，結晶粒度 9.2 材 が同粒度 7.0 材に比べて大幅に増加することから, 結晶粒 度が小さなるほど発生高さが低くなり，結晶粒度の依存 性が明確に認められる。また，二次加工脆化の割机破面は， 結晶粒度 8.2 材で観察した結果, Fig. 5に示されるように, 粒界破壊破面を呈していることが確認された。

次に, B 無添加材に打ける機械的性質に及济す焼鈍温度

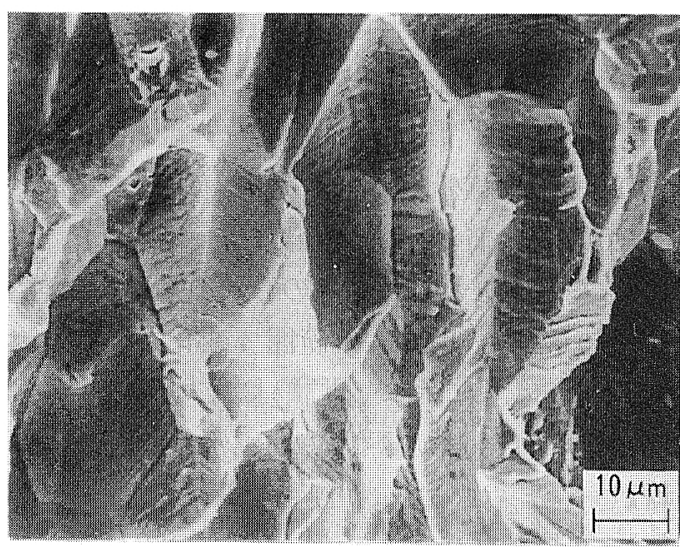

G.S.N. $\quad: 8.2$

Falling height: $300 \mathrm{~mm}$

Fig. 5. Fractograph of cylindrical cup fractured at $25^{\circ} \mathrm{C}$ for Ti-added ferritic stainless steel (B : $2 \mathrm{ppm})$
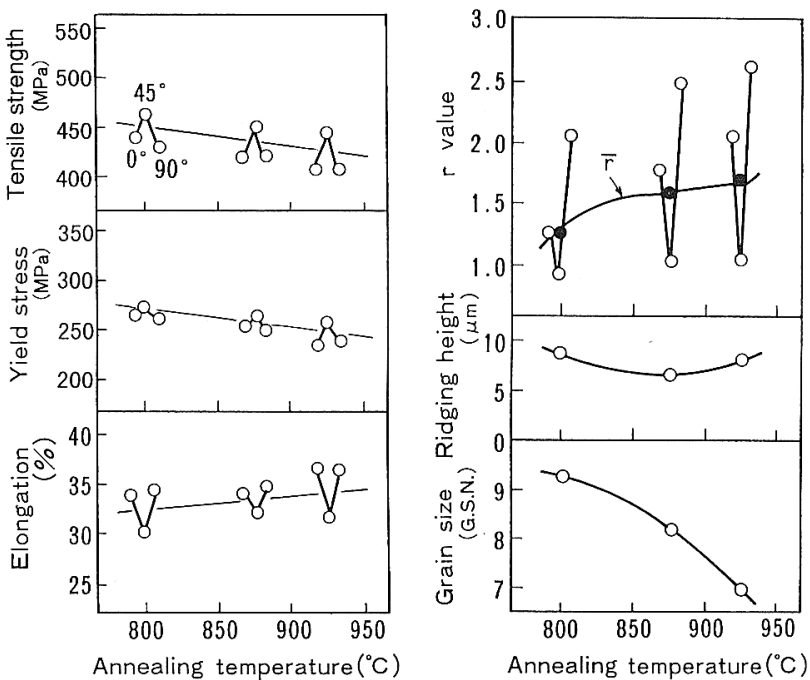

Fig. 6. Effect of annealing temperature on mechanical properties of Ti-added ferritic stainless steel (B: $2 \mathrm{ppm})$.

の影響を Fig. 6に示す。結晶粒度が7.0から 9.2 に変化する 場合，引張強さや降伏応力は僅かに上昇し，逆に伸びはや や低下する。引張特性の異方性は，今回調查した結晶粒度 の範囲内で同程度である。また, 引張変形後のリジング高 さは $6 \sim 9 \mu \mathrm{m}$ とほとんど変化していない。一方，r值は， 次式に基づいて計算される平均 $r$ 值（以下， $\bar{r}$ 值と呼ぶ） で見ると，結晶粒度が小さくなると低減する。

$$
r=\frac{r_{0}+r_{90}+2 \times r_{45}}{4}
$$

ここで， $r_{0}, r_{45}, r_{90}$ は圧延方向に対して $0^{\circ}, 45^{\circ}, 90^{\circ}$ 方向 の $r$ 值である。二次加工性が良好である結晶粒度 9.2 材で は深絞り加工に必要な

従って，B無添加材における二次加工脆化は粒界破壞に より発生し結晶粒度に依存するため，細粒化により改善さ れるが，深絞りの指標である什值の低下が大きいことがわ 


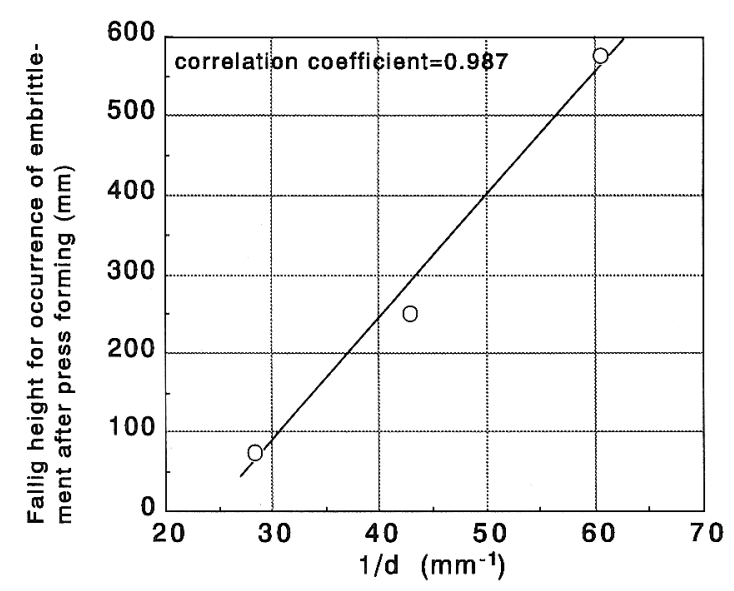

Fig. 7. Relationship between grain size and falling height for occurrence of embrittlement after press forming.

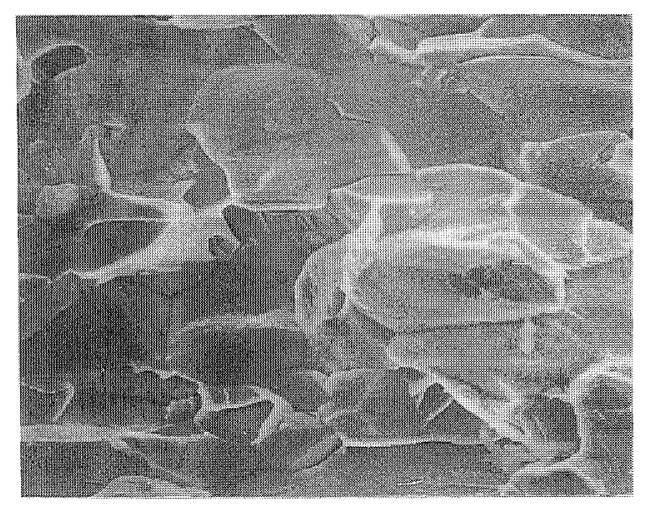

B $: 2 \mathrm{ppm}$

Falling height: $300 \mathrm{~mm}$

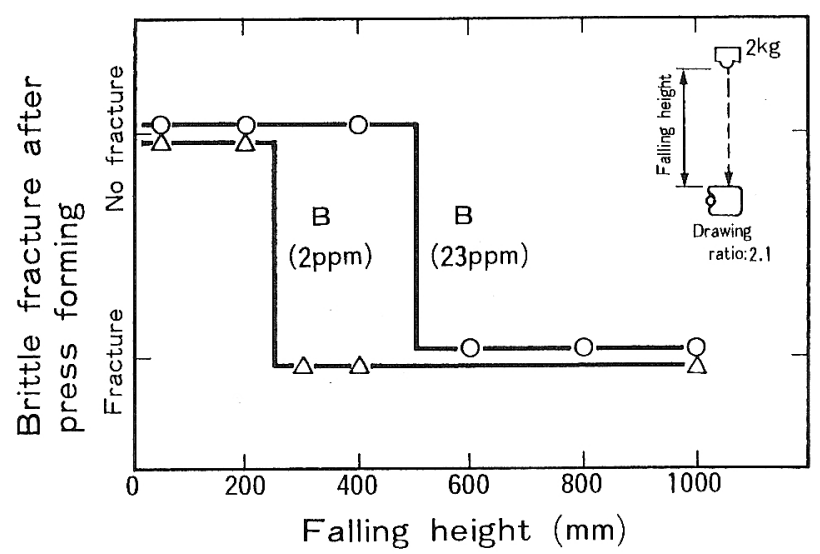

Fig. 8. Effect of boron on falling height for occurrence of brittle fracture after press forming at $10^{\circ} \mathrm{C}$. (G.S.N.: $8.6 \sim 8.7$ )

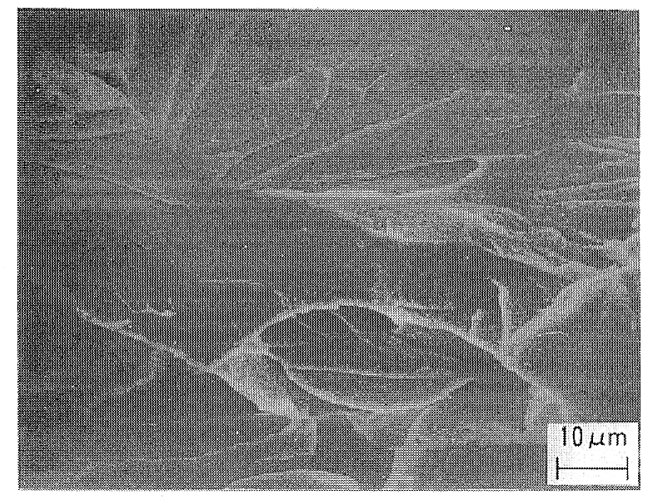

B :23ppm

Falling height: $600 \mathrm{~mm}$

Fig. 9. Effect of boron on fractographs of cylindrical cups fractured at $10^{\circ} \mathrm{C}$ for B,Ti-added ferritic stainless steels.

かる。

細粒化による二次加工脆化の改善効果について若干考察 する。結晶粒の細粒化は, 粒界面積増大による粒界破壊に 要する仕事の上昇効果 ${ }^{13}$ あるいは粒界での応力集中の緩和 効果 ${ }^{14)}$ 等がまず想定される。本実験の場合, 粒界破壊に要 する仕事は落重高さに比例するはずである。また，結晶粒 を一辺dの立方体とすると単位体積当たりの粒界面積が $3 d^{2} \times\left(1 / d^{3}\right)=3 / d$ となる。そこで, 粒界面積増大効果が落重 高さ $h$ と結晶粒径 $d$ の関係に打いて次式の反比例式として 表されると仮定し図示すると，Fig.70ように示される。

$$
h \propto \frac{1}{d}
$$

同図から, 二次加工脆化発生の落重高さ $h$ は, $1 / d$ と極 めて良い相関が認められる。従って，B無添加材で認めら れた結晶粒の細粒化による効果は, 幾何学的な粒界面積の 増大により粒界破壞に要する仕事の上昇効果が主体である 可能性が高いと考えられるが，粒界構造を考慮した詳細な 検討により今後確認していく必要があるう。

\section{$3 \cdot 2$ B添加の影響}

深絞り加工性を確保しつつ, 而二次加工脆性を改善する ためには, 結晶粒の細粒化は有効な方法でなく, 粒界強化 による耐二次加工脆性の向上が必要で西る。元こで，粒界 強化の点から $\mathrm{B}$ 添加の効果について検討を行った。

二次加工脆化の発生高さに及ぼすB添加の影響を Fig. 8 に，脆化の割机破面の走查電子顕微鏡像 Fig. 9 に示す。 二次加工脆化の発生高さは, $23 \mathrm{ppm}$ の B添加材が $2 \mathrm{ppm} の$ $\mathrm{B}$ 添加材に比べて約 2 倍に増加することがわかる。一方， 脆化の割れの形態は粒界破壞を呈している破面からへき開 破壊の破面に変化している様子が認められる。

二次加工脆化の発生温度に及ぼす B 添加の影響を Fig.10 に示す。各B添加量に打ける結晶粒度を図中の( )内の数 字で明記している。二次加工脆化の発生温度はB 添加によ り低温化することがわかる。特に, B 添加量が $20 \mathrm{ppm}$ 程度 までの範囲で低減効果が著しく, 発生温度は $\mathrm{B}$ 添加量が $10 \mathrm{ppm}$ 当たりで約 $20^{\circ} \mathrm{C}$ 低下する。 $\mathrm{B}$ 添加量が $20 \mathrm{ppm}$ を超 えると低減効果がやや飽和する傾向が認められる。

機械的性質に及ぼす B 添加の影響を Fig.11に示す。B添 加量が増元ると, 引張強さおよび降伏応力は上昇し, 逆に 


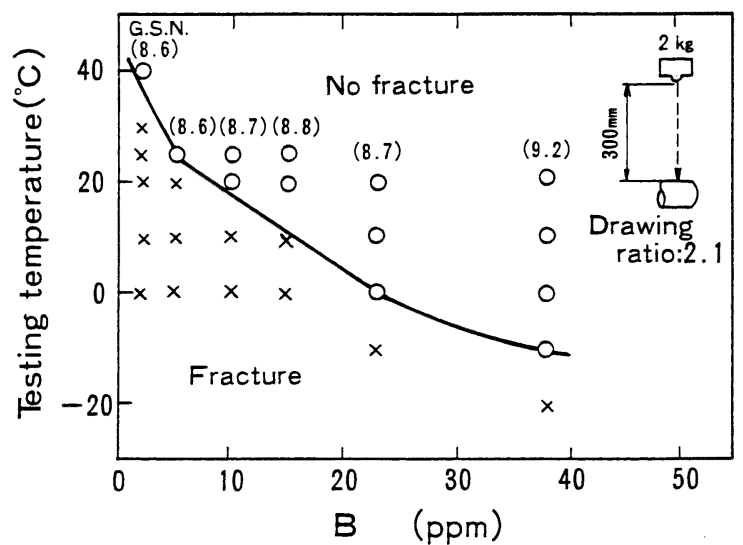

Fig. 10. Effect of boron on brittle fracture after press forming of $\mathrm{B}$, Ti-added ferritic stainless steels. (Annealing temperature: $850^{\circ} \mathrm{C}$ )
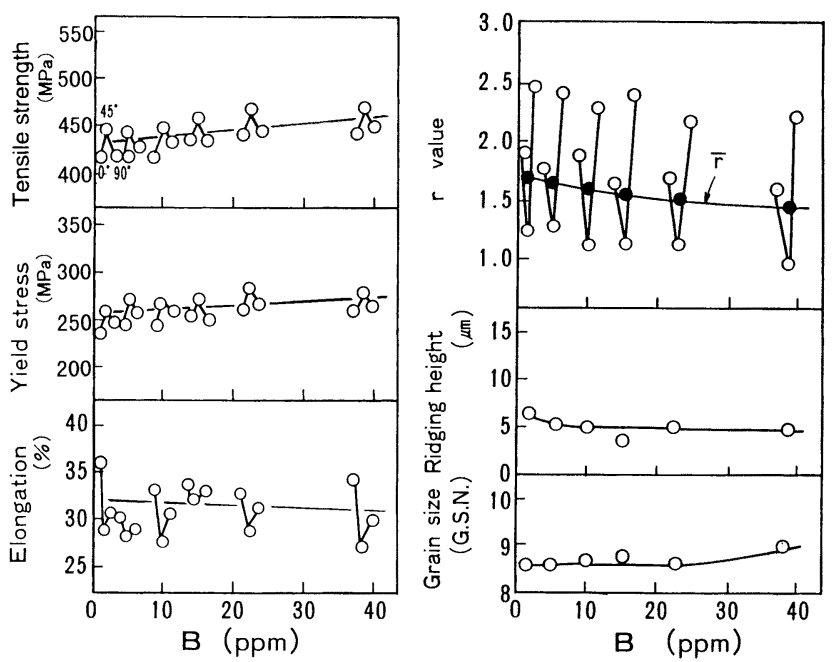

Fig. 11. Effect of boron on mechanical properties of B, Tiadded ferritic stainless steels. (Annealing temperature: $850^{\circ} \mathrm{C}$ )

破断伸びは減少する傾向があり，Bによる硬化の影響が認 められるが，その程度は僅かである。一方，引張特性の異 方性は，若下バラツキがあるもののB添加量の影響は小さ い。また, リジング高さは, B 添加量が増えても約 $5 \mu \mathrm{m}$ とほぼ一定であり，B添加の影響が認められない。さらに， 結晶粒度も，38 ppm材で若干細粒気味になるが，23 ppm 以下約 8.7 とほぼ一定であるので，B添加の影響は小さい。 $\bar{r}$ 值は，B添加量が增えると若干低下する傾向を示すが， 前述した結晶粒度の影響に比べて小さく，耐二次加工脆性 の改善の効果の大きい約 $20 \mathrm{ppm}$ 程度までは深絞り加工に 必要な 1.5 以上を確保できることがわかる。

従って，0.5\%Ti 添加した低炭窒素の $17 \mathrm{Cr}$ フェライト 系ステンレス鋼はB 添加により引張特性がほとんど変化さ せずに, 深絞り加工性を維持しつつ耐二次加工脆性を向上 させることできる。

$r$ 值に及ぼす $\mathrm{B}$ 添加の影響について，集合組織の点から 調查した。その結果, 最終焼鈍板におけるX線相対面強度

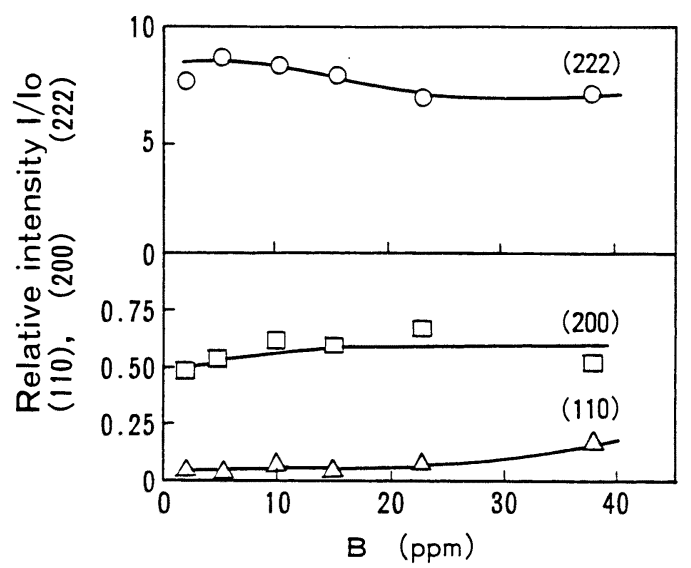

Fig. 12. Effect of boron on X-ray diffraction relative intensity of B, Ti-added ferritic stainless steels.

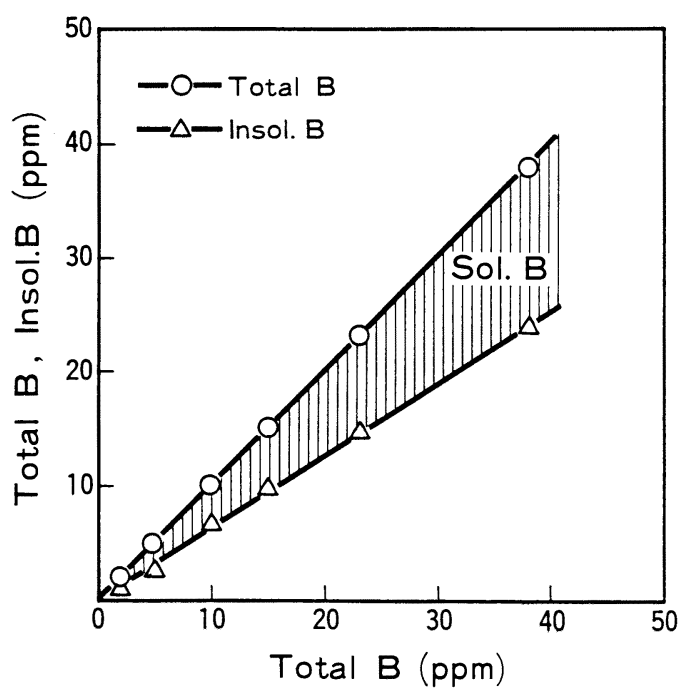

Fig. 13. Analytical results of insoluble boron in extracted residues and total boron.

に及ぼす B 添加の影響を Fig.12に示す。什を向上させる 面方位の(222)相対強度がB 添加により若干減少し，逆に $\bar{r}$ 值向上にとって良くない面方位の(200), (110)相対強度が僅 かに增加する。このため， B 添加により六值がやや低下す ると考えられる。

次に, Bの存在形態を明らかにするために，最終焼鈍板 の析出 B量を測定し，析出物およびBの分布を観察した。 抽出残渣による最終焼鈍板の析出 B 量の分析結果を Fig.13 に示す。斜線は $\mathrm{B}$ 添加量と析出 $\mathrm{B}$ 量の差を示す。固溶 $\mathrm{B}$ 量 は，この差に相当すると考えると，B添加により増加する ことがわかる。抽出レプリカ法による最終焼鈍板における 析出物の分布を Fig.14に示す。この透過電子顕微鏡写真は, 粒界三重点を中心に示しており，粒界が見えにくいので， 粒界を“GB”という記号で明示した。B添加量が $2 \mathrm{ppm}$ 材お よび $23 \mathrm{ppm}$ 材とも析出物の形態はほぼ同じであるが，析 出物の分布は $23 \mathrm{ppm}$ 材がやや密である。B添加による析出 物の増加は粒界に比べ粒内の方が顕著である。電子線回析 


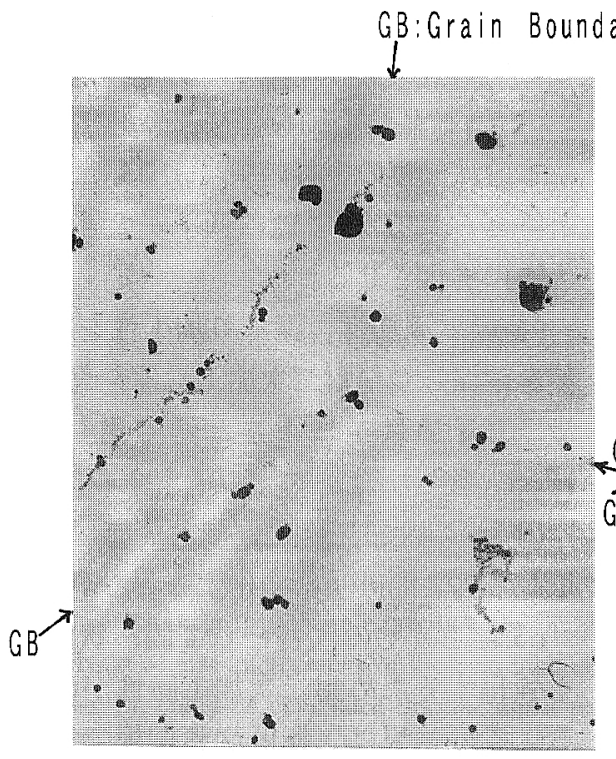

B : $2 \mathrm{ppm}$

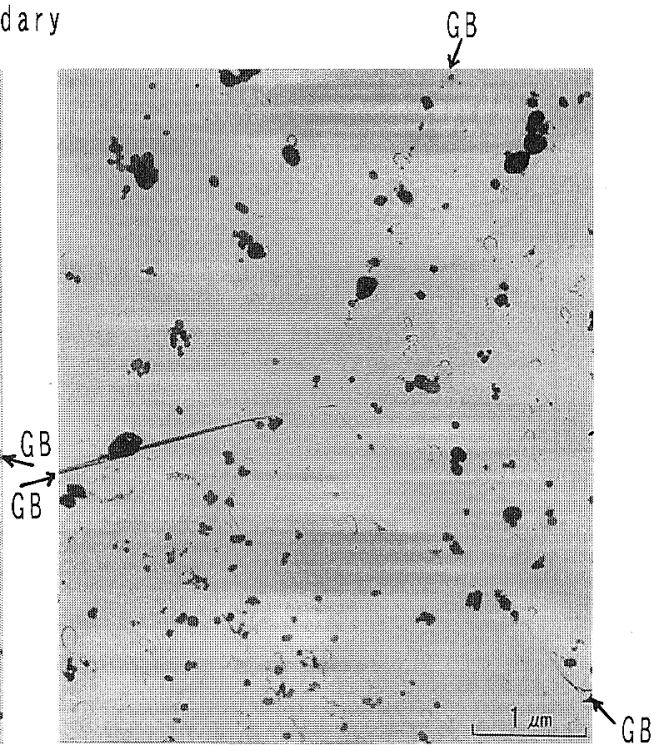

B : $23 \mathrm{ppm}$

Fig. 14. Extraction replicas of $\mathrm{B}$, Ti-added ferritic stainless steels.

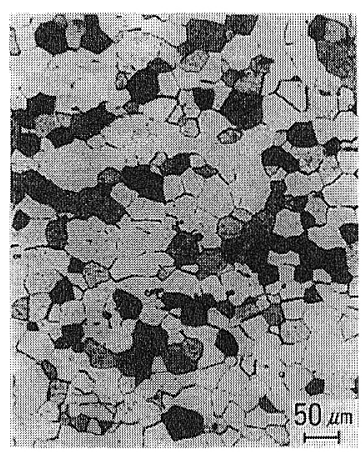

Microstructure

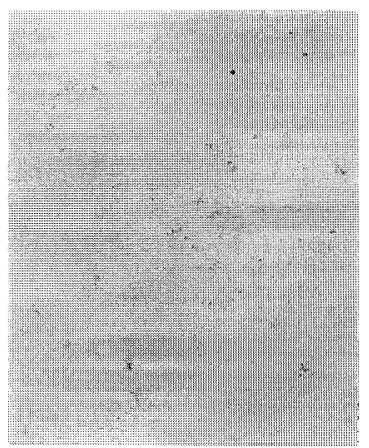

B : $2 \mathrm{ppm}$

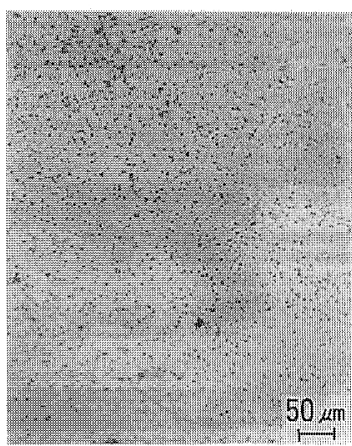

B : $23 \mathrm{ppm}$

Boron distribution patterns

Fig. 15. Microstracture and boron distribution patterns by fission-track method for B,Ti-added ferritic stainless steels.

により一部の析出物は TiCまたは TiNと同定できたが，ほ とんどのものは明確に同定できなかった。最終焼鈍板の組 織とフィッショントラック法によるBの分布を Fig.15に示 す。 $23 \mathrm{ppm}$ 材に打けるBの存在は, 組織の結晶粒と $\mathrm{B}$ の存 在を示寸黒斑点の分布との比較から粒内に比べて粒界に沿 って認められることがわかる。

以上の観察結果に基づいて， B添加による粒界強化効果 について考察した。添加されたBは析出物として粒界や粒 内に存在するものもあるが，Cと同様に拡散しやすいため 主として粒界へ偏析していると考光られる。BはC の化学的性質を有することから，Bによる粒界強化はCに 対して提案されているモデルと同様に考元られる。すなわ ち, モデル〈a〉は，粒界への偏析位置が C（あるいはB）原 子と $\mathrm{P}$ 原子で同じであるため固溶 $\mathrm{C}(\mathrm{B})$ 量の増加により $\mathrm{P}$ 原 子の偏析を防止し粒界を強化する説 ${ }^{10)}$ ，いわゆるサイトコ ンペティション効果である。この効果は, CとPの平衡粒
界偏析において存在することが報告されている ${ }^{10,15) か ゙ ， B ~}$ と $\mathrm{P} の$ 間で存在寸るか, あるいは本実験のような平衡粒界 偏析でない状態で存在するかはIF鋼板においても確証が 得られていない。また, モデル〈b〉は, 固溶 $\mathrm{C}(\mathrm{B})$ 原子が粒 界に偏析した $\mathrm{P}$ 原子による $\mathrm{Fe}-\mathrm{Fe}$ 結合力に及ぼす負作用を 打ち消す説 15 である。これは，化学的相互作用仮説とよば れているものであるが，固体中における C (B)とPの間で 化学的結合力はまだ発見されていない(16)。さらに，モデル 〈c〉は，固溶 C (B)原子自体による粒界の Fe-Fe結合力を強 化する説 ${ }^{16)}$ である。この粒界の結合力について，不純物原 子間結合力が昇華熱に比例すると近似して，昇華熱が大き い不純物ほど表面張力を増加させ，粒界脆化を抑制すると して，B流 C と同様に粒界の結合力を高める元素に位置づ けられていることが報告されている17)。さらに，Bに対す る粒界結合力の電子論的な解析から, B が Fe-Feの金属結 合から電子を取込むことなく，逆に $\mathrm{Fe}$ 原子との共有結合 


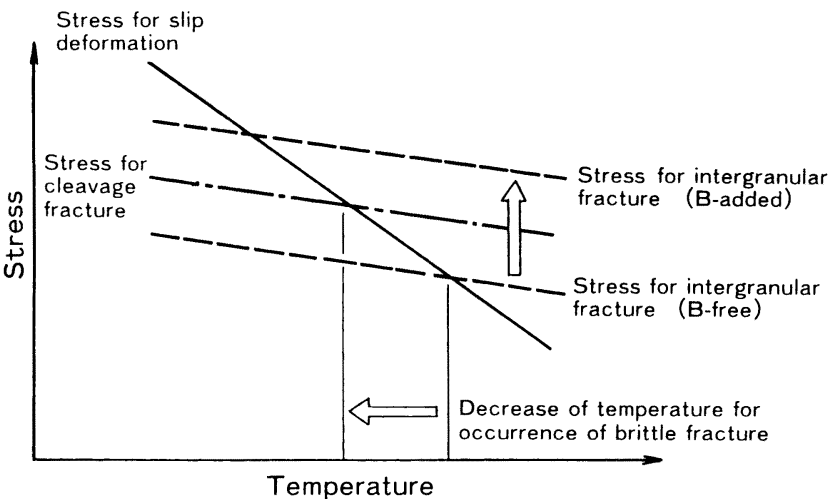

Fig. 16. Schematic illustration for effect of boron on improvement of embrittlement after press forming.

を形成し，粒界結合力を高めることが示されている ${ }^{18)}$ 。現 在, モデル〈c〉が最も有力視されている説であるが, 研究 が進んでいるIF鋼板においても確証が得られていない。 しかしながら，いずれのモデルにおいても，粒界に偏析し た固溶 $\mathrm{B} か ゙ \mathrm{TiC}$ 析出により不足した固溶 $\mathrm{C}$ の代替として粒 界を強化することは共通して言えることと考えられる。

そこで， 二次加工脆化に対する B添加の効果について， 破壊応力とすべり変形応力の関係から模式的に示した図を Fig.16に示す。この図は, 粒界破壊応力, へき開破壊応力 およびすべり変形応力の温度依存性を模式的に示してい る。 $\mathrm{B}$ 無添加材の場合, Ti添加により固溶 $\mathrm{C}$ 量が減少し粒 界破壊応力がへき開破壊応力に比べ低下するため二次加工 脆化が粒界破壊により発生すると考えられる。一方，B添 加材では粒界に偏析した固溶 B により粒界破壊応力がへき 開破壊応力に比べ高くなるため，二次加工脆化はへき開破 面を呈するようになる。従って，B添加により破壊形態が 粒界破壊からへき開破壞へ移行する温度分が二次加工脆化 の発生温度を低温化すると考えられる。

\section{4. 結言}

高純度フェライト系ステンレス冷延鋼板の耐二次加工脆 性に及ぼす結晶粒径およびボロンの影響を調査・解析した 結果，以下の知見が得られた。

（1） $0.5 \% \mathrm{Ti}$ を添加した低炭窒素 $17 \mathrm{Cr}$ フェライト系ス
テンレス鋼板の二次加工脆化は，粒界破壊により発生する ことを明らかにした。

（2）結晶粒の細粒化は, 幾何学的な粒界面積の増大に よる破壊仕事の上昇効果により耐二次加工脆性を改善する と考えられるが，值の低下が大きいため深絞り加工性を 大幅に劣化させる。

（3） B 添加は, 深絞り加工性を維持できる 1.5 以上の $\bar{r}$ 值を確保しつつ耐二次加工脆性を改善する。割れ発生温度 は，B添加量が増えると低温化し，20 ppmの範囲まで

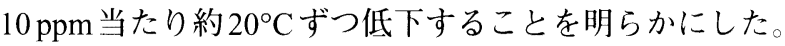

（4）二次加工脆化の割れ形態は, B 添加により粒界破 壊からへき開破壊に変化することが判明した。

（5）BがCの代替として固溶状態で粒界へ偏析し粒界 を強化するため耐二次加工脆性が改善されると考えられ る。この結果は, 極低炭素鋼板で得られた知見と一致す る。

\section{文献}

1 ) 澤谷 精, 清水邦彦, 中山正, 平井卓：鉄と鋼、63 (1977), 832

2 ) 澤谷 精, 清水邦彦, 中山正, 三好埧：鉄と鋼，63 (1977), 843

3 ) 宮楠克久, 植松美博, 星野和夫：鉄と鋼，69(1983), A296

4 ）宮楠克久，植松美博，星野和夫：鉄と鋼，72 (1986), S595

5 ) 清水峰男：京都大学工学研究科博士論文, (1972).

6 ) N.Takahashi, M.Shibata, Y.Furuno, K.Hayakawa, K.Kakuta and K.Yamamoto: Proc. of Symp. on Metallurgy of Continuous-annealed Sheet Steel, Met. Soc. AIME, New York, (1982), 133.

7 ) 酒匂雅隆, 田山勝彦, 下村隆良, 荒木健治：鉄と䤱，70 (1984), S1251.

8 ) 山田正人，徳永良邦，山本満治：鉄と銅，73 (1987), 1049

9 ) E.Yasuhara, K.Sakata, T.Kato and O.Hashimoto: ISIJ Int., 34 (1994), 99.

10) H.Erhart and H.J.Grabke: Met. Sci., 15 (1981), 401

11) H.Tada and A.Yoshikawa: Trans. Iron Steel Inst. Jpn., 11 (1971), 1256

12）田賀秀武，吉川明静：金属忉料技術研究所報告，15(1972), 57 .

13）小西元幸, 大橋延夫, 吉同 博：川崎製鉄技報，6(1974), 305 .

14）幸田成康：改訂金属物理学序論，コロナ社。東京，(1973), 296.

15) S.Suzuki, M.Obata, K.Abiko and H.Kimura: Scr. Metall., 17 (1983), 1325

16)鈴木 茂, 小畑 稔, 安彦兼次, 木村厷: 鉄と鋼、70 (1984), 2262

17) M.P.Seah: Acta Metall., 28 (1980), 1395.

18) R.P.Messmer and C.L.Briant: Acta Metall., 30 (1982), 457. 